University of Louisville

ThinkIR: The University of Louisville's Institutional Repository

Electronic Theses and Dissertations

6-1916

\title{
Analysis of the water insoluble proteins of beef, pork and mutton by the Van Slyke method.
}

Edward H. Cox

University of Louisville

Follow this and additional works at: https://ir.library.louisville.edu/etd

\section{Recommended Citation}

Cox, Edward H., "Analysis of the water insoluble proteins of beef, pork and mutton by the Van Slyke method." (1916). Electronic Theses and Dissertations. Paper 285.

https://doi.org/10.18297/etd/285

This Master's Thesis is brought to you for free and open access by ThinkIR: The University of Louisville's Institutional Repository. It has been accepted for inclusion in Electronic Theses and Dissertations by an authorized administrator of ThinkIR: The University of Louisville's Institutional Repository. This title appears here courtesy of the author, who has retained all other copyrights. For more information, please contact thinkir@louisville.edu. 
ANALYSIS OF THE WATER INSOLUBLE PROTEINS OF

BERF, PORK AND MUTTON,

BY THE VAN SLYKE MRTHOD.

by

Bdward H. Cox

Submitted in partial fulfillment of the requirement for the degree of Master of Science in chemistry, in the college of Arts and Solences of the University of Louisvillo. June 1, 1916. 
Analysis of the Water Insolable Proteins of Beef, Pork and llutton.

So far as the author has been able to I1nd, there are no published analyses show ing the relative composition of the most important used meat proteins, beef, porl and mutton, tho Obborne and co-rorkers have published analyses of the water insoluble proteins of the musole substance of ox ${ }^{1}$, chicken ${ }^{2}$, $1 \mathrm{sh}^{3}$, and soallop ${ }^{4}$. Th1s paper gives the reault of analyses, by the Van slyke method, of the water insoluble, fat-free proteing of beef, pork, and mutton.

Preparation of the samples: The samples of meat were purchased from a local dealer, the animals in each case having.been killed three days previously. The exaot age of animals was not known, tho the ox was estimated to be throe, the hog two, and the sheop tro years old. The ox cut was made from the rump and the hog and mutton made from corresponding leg cuts. The connective tisgue and fat of each sample were removed as far as possible by outting and rinsing with water to remove the adhering particles. They were ground in an ordinary meat grinder, allowed to stand for thirty minutea and filtered thru double cheese oloth. The residues which contained some blood were again allowed to stand two hours in water and again

1.' Osborne and Jones: Amer. Jour. Phys101, 24, 437 (1909).

2. Osborne and Heyl: Ibid., 22, 348 (1908).

3. Osborne and Heyl: Ib1a.., 23, B1 (1908).

4. Osborne and Jones Ib1d., 24, 161 (1909). 
filtered and preased to remove the Inal traces of water and ooluble matter. This process gave a white stringy mass of protein. The water insoluble portion were aried in an electric oven at $60^{\circ}$ for twelve houra and finally dried in vacuum desicostors for forty hours. The dried samples were ground in a mortar and run thro a thirty-five mesh sieve. By this means small amounts of fibrous connective tisgue were remored, the amounts being greatest in the case of the beef, lese in the pork and still lese in the mutton. The white pralpy masses were noticabl hygrosoopic and were aried again at $60^{\circ}$ before veighing.

Weight of beef before washing

(a) Woight after washing and drying

Fater and extractives
250 grams

42.6 grame

88.9 per oent.
Weight of pork before rashing

(b) Welght after washing and drying Nater and extraotives
194 8rems

39.4 grams

79.7 per cent.

Weight of mutton before washing

(o) Weight after washing and drying

Water and extraotives

150 grams

28.6 grams

75.0 per cent. 
Ash: Samples of each protein were incinerated in quartz dishes for thirty-five hours, A fow orystals of ammonium nitrate were added during the hoating. The residue in each case was pure white.

Weight of ary sample of beef

(a) Weight of ash

Per cent of ash

2.638 grams

0.0178 grams

0.675

Weight of ary sample of pork

(b) Weight of ash

Per cent of ash

3.011 grams

0.0367 grams

1.78

Weight of dry sample of mutton

(0) Weight of esh

Per cent of ash

1.289 grams

0.0104 grams

0.807 
Fat: The samplea were extraoted twenty-four hours with dry ether, in an extraotive apparatus.

Weight of dry sample of beef

- (a) Weight of ether residue

11.01 grams

7.589 Brame

Por cent of ther oluble material 14.48 .

Teight of dry sample of pork

(b) Weight of ether residu

Per cent of ether ooluble mater 1al

10.254 8rame

1.917 Brams 18.78 .

Weight of dry sample of mutton

(o) Weight of ether residu

9.649 grame

Per cent of ether soluble material

0.641 grams

6.24 . 
The Van Slyke method ras follored in the analysis. Instead of the ofl bath, oommonly used, in the hydrolysing process, on automatio electric oven was used to exoellent advantage. A condenser was lead thru a hole in the top and provided with a thermometer. By thio means a constant temperature was easily maintained thruout the hydrolysis, with no danger of over-hoating. In the arginine determination. after the usual digestion with alkali, a current of amnonia. free air was forced thru the flasks for ten minutes, to sweep into the Folin bulbs the ammonia whieh might remain orer the liquid in the flasks. The sabsequent diotillation, to ecore the ammonia that might be absorbed by the liguid in the flarks, was performed as usual. In determining the total nitrogen in the flltrate from the bases great difficulty was experlenoed. when attempts were made to distil off the ammonia, on sooount of bomping. To obviate this, the amonia was remored by aspiration for twelve hows. In each case duplioates showed close agreement.

Van Slyke's improved method for the deogmposition of the basie phosphotungstate wa used, 1.e. the ure of ether-amyl-aloohol as a solvent for phosphotungstio aold,

$$
\text { 1. Van slyke: J. B10l. Chem. } 22 \text { 281(1915). }
$$


instead of the use of barium hydroxido as a precipitent. Tho this method has certain advantages, the quantity of ether-amylaloohol necessery to remove the phosphotungetic aoid was found to be quite great.

After the preolpitation of the baees with phosphotungstic acid and subsequent parming on a water-bath, a violet color developed in the liquid in which the proolpitate was strpended. This color was most prominent in the case of the beef and pork with but little color in the case of the matton. Such oolor variation suggest a difference in the amount of tryptophan in the proteins, as this reaction is characteriatio of this amino-acid ${ }^{1}$. (Hopkins-Cole Reaction).

Hydrolysis of the fat-free cample of protein was found to be complete in thirty houre, as shown by a constant rolume of nitrogen in the aminometer. In each case, the concentrated solution of amino-aolds was dilated to 100 oc. and 5 oc. portions taken for the determination of total nitrogen.

1. Hethews: text Physiol. Chem. (p 151). 
Analyois of Beef Protein:

Weight of sample of ary beef protein Amount of Protein in $80 \mathrm{co}$. solution

6.724 8rame. , $4.507872 m$.

Total Nitrogen: The omounts of $\mathrm{N} / 10$ zoid neutraliged vere 31.2 and $31.200 .$, giving a nitrogen oontent of 0.6988 grams of nitrogen in 80 co. oolution need for analjais.

Eetimated total nitrogen of sample 0.6988 grams or 15.56 per oont.

Ammonia: The amount of $\mathrm{N} / 10$ aold neutralised was 87.8800. giving $0.0589^{\circ}$ grams of amid nitrogen.

Kelanin: The amount of II/ 10 aold neutralieed was 1.8 oc., indloating 0.0025 grams of melenin nitrogen.

Cyotine: No weighable preolpitate of $\mathrm{BasO}_{4}$ resulted indicating the absence of this body. (Donie' modfication of Benedict's method for totel sulfur was noed).

Arginine: The amount of $1 / 10$ acid neutralised was $10.500 .$. for 40 ce. solution indicating 0.0721 grams of arginine nitrogen in 100 co. solution.

Total Nitrogen of the Beses: The amount of $1 / 10$ acia neutralleed was 66.6 o0.: this smount sded to thet noutralised in the arginine determination gave $66.9 \mathrm{00.}$, indioating .2341 of total nitrogen.

Amino Hitrogen of the Bases: The mounts of ges erolrod from duplicete portions of 1000. solution were 24.5 and 84.500 .4 at $21^{\circ}, 745 \mathrm{~mm}$. giving . 1349 gram of anino nitrogen in 100.0. solution.

Amino Nitrogen of the Filtrate from the Bases: The emount of gas evolved from tro separate portions of $10 \mathrm{os}$. Holution was 33.5 co., at $21^{\circ}, 745 \mathrm{~mm}$, 8 tring .3905 grame of amino nitrogen.

Total Nitragen of the Filtrate: The amornte of $1 / 10$ and neutralised were 14.9 and $14.3 \mathrm{oc}$. f for 1000 . portions of olntion giving .4088 grame of nitrogen in 20000 . volution.

1. v. Denis. J. Biol. Chem. 8401 (1910). 


\section{Table I.}

Results of Beef Analysis in Grams and Percentage of total Nitrogen.

Weight of protein sample

$\begin{array}{ll}\text { Weight of total nitrogen } & 0.6988 \\ \text { Per cent of Nitrogen in protein } 15.65\end{array}$

4.507 grams

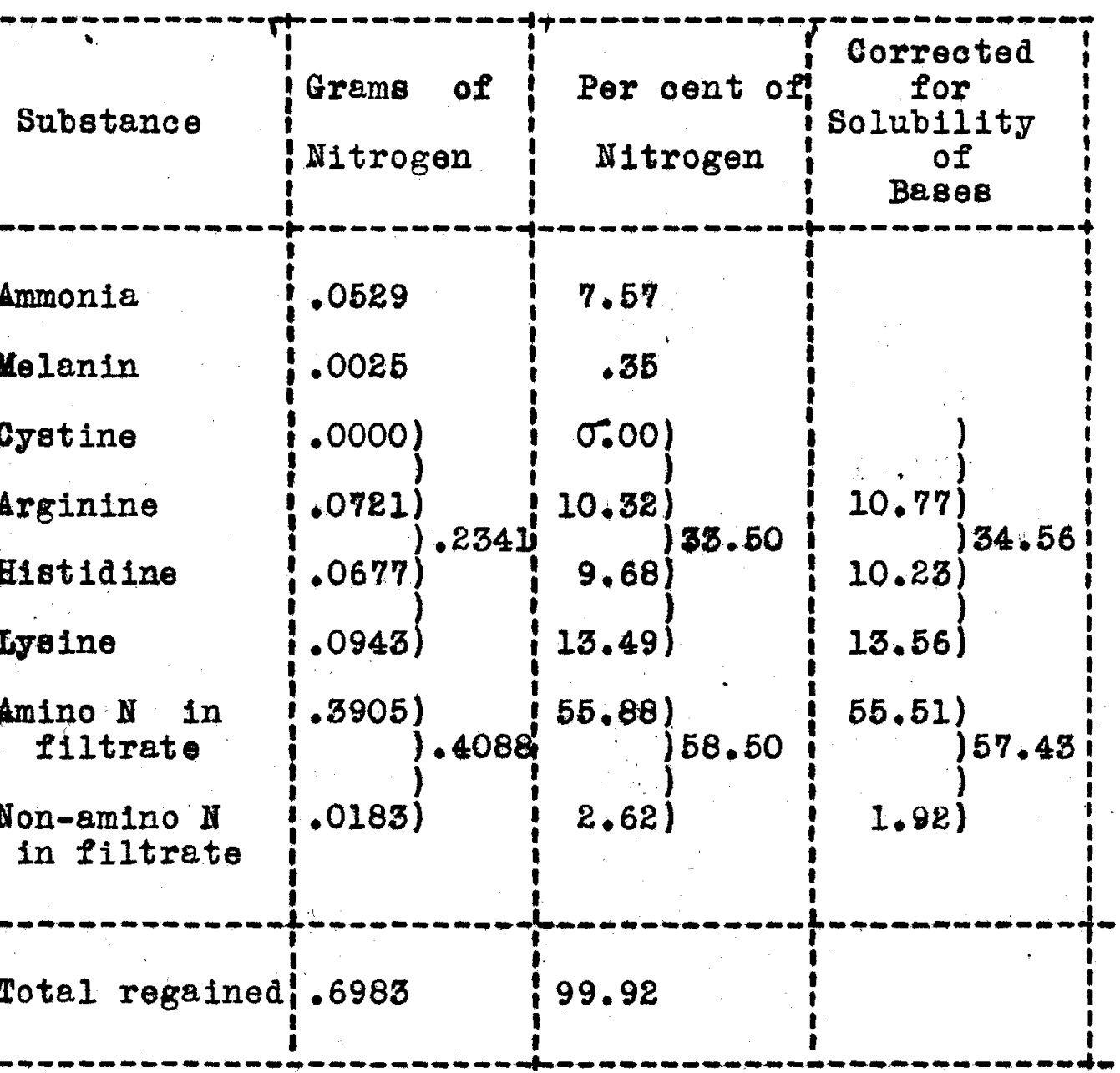


Analyeis of Pork Protein!

Weight of cample of ary pork protein:

Amount of Protein in $80 \mathrm{co}^{-}$. solution used:

5.460 grams

4.454 grana

Total Hitrogen: The amounts of $N / 10$ acid neutralised were 30.5 and 30.300. for 5 oc. portions of solution, giving a nitrogen oontent of .6884 gram in $80 \mathrm{co}$. of solution used for analysis.

Eatimat ed total nitrogen of eample 0.6884 or 15.32 per cont.

Ammonia: The amount of $Y / 10$ acid neutralised va 40.1 a0. giving .0561 grems of emid nitrog $\mathrm{m}$.

Melanin: The amount of $1 / 10$ a01a neutralised was 9.700. giving .0135 grame of melanin nitrogen.

Oyetine: No ve1ghable precipitate of $\mathrm{BasO}_{4}$ rearited.

Arginine: The mount of $I / 10$ aold neutralised new 9.000. for 40 co. solution, giving .0694 grams of arginine nitrogen in 100 co. solution.

Total Nitrogen of the Based: The amount of $\mathrm{N} / 10 \mathrm{ac1}$ nentralised was $52.1 \mathrm{oo.;}$ this amount aded to that nentralied In the arginine gave $6200 .$, in $40 \mathrm{co}$. solutios, Indiosting .817 grams of nitrogen.

Amino Nitrog on of the Bases: The amount of gas evolrod from duplicate portion of 10 co. olution was 23.5 00.. at $21^{\circ}, 745 \mathrm{~mm} ., \mathrm{giving} .1299 \mathrm{grams}$ of amino nitrogen in 100 co. solution.

Amino Nitrogen of the Filtrate from the Bases: The amount of gas evired from duplicetes portions of 1000. volution was 3400 , at $21^{\circ}, 746 \mathrm{~mm}$, giving .376 grams of amino nitrogen.

Total Nitrogen of the Filtrate: The amounts of $1 / 10$ aold ne utral is ed were 35.1 and 36.1 00.. for 2500 . portions of solution, giving .3987 grams of nitrogen in 800 oc. solution. 
Table II.

Result of Pork Analysis in Grams and Percentage of total Nitrogen.

Weight of protein ample

Weight of total nitrogen?

Per cent of Hitrogen in protein

4.454 grams

0.6824 grams

15.32

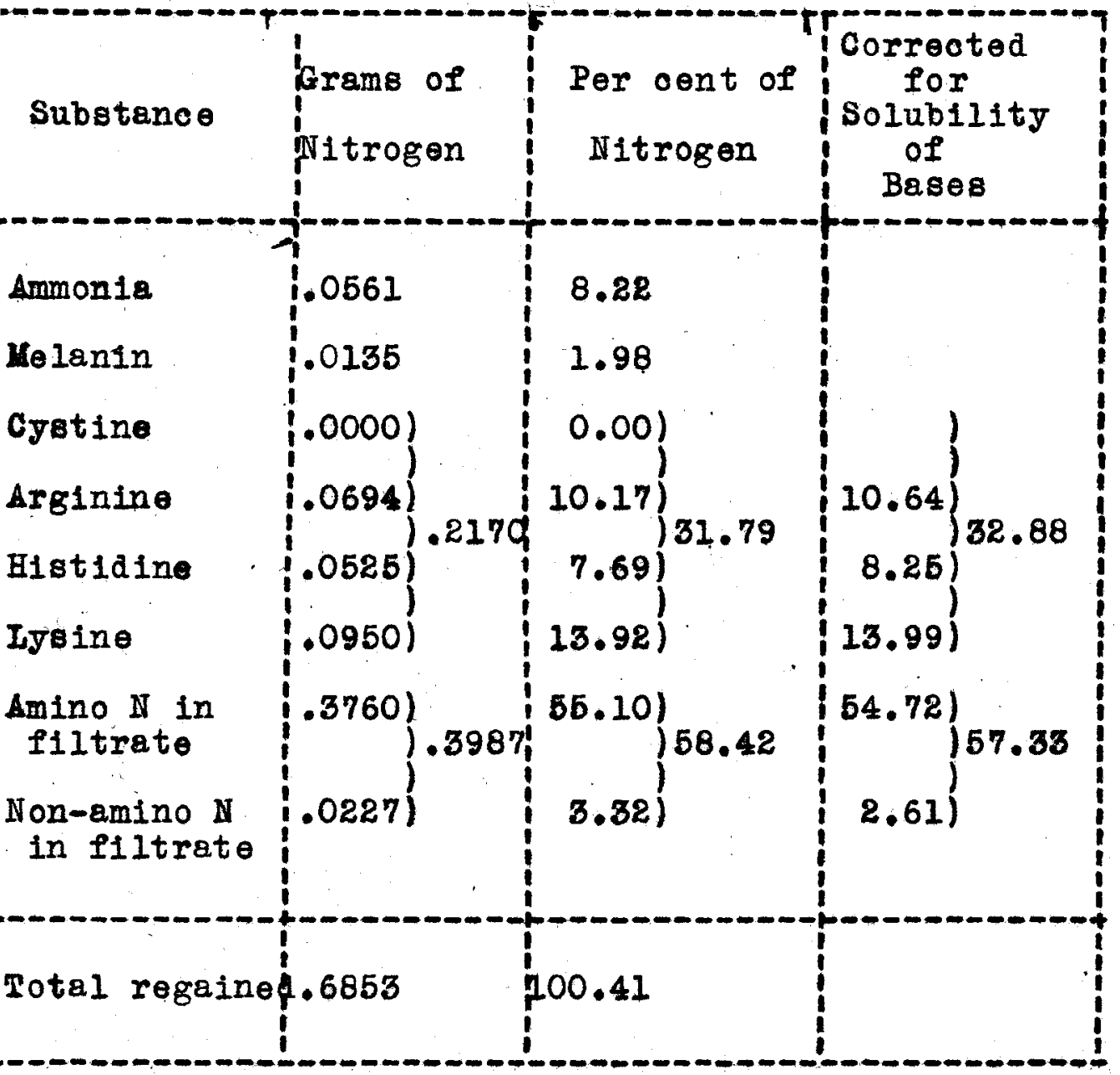


Analyeis of Untton Protein:

Weight of the eample of dry protein:

Weight of Protein in $80 \mathrm{cc}$. Bolution used

6.6766 gram

4.264 grame.

Total Hitrogen: The amount of $\mathrm{H} / 10$ acid nentralised were 29.9 and $30.3 \mathrm{oc}$., for 5.00 . portions of solution, giving a nitrogen. content of .6744 gram in 80 oo. used for analys is.

Eatimated total nitrogen of sample 0.6744 or 15.85 per cent.

Ammonia: The amount of $1 / 10$ sold neutralised was 38.300. , giving .0078 grams of melea in nitrogen.

lielanin: The amount of $1 / 10$ acid neatralised wa 5.600. giving .0078 gram of melen in nitrogen.

Ogetine: No weigheble preolpitate of $\mathrm{BasO}_{4}$ resulted.

Arginine: The amount of $\mathrm{H} / 10$ acid noutralised was 6.100. for 40 oc. solution, giving .0867 grams of arginine nitrogen in 100 os. 60 lution.

Total Nitrogen of the Bases: The amount of $\mathrm{H} / 10$ acia neutralieed was 27.3 00.; this emount added to that nevtrelised in the arginine determination, gabo $38.400 .$, Ind loating .1134 grams of nitrogon.

Amino Vitrogen of the Basea: The amount of ges erolred Irgm anplioate portions of 1000 . colution was $1800 .$, at 210.746 ma., giring .0663 gram of amino nitrogen.

Amino Nitrogen in the Filtrate for the Bases: The omount of gas evolved from duplicate porticas of $10 \mathrm{co..}$ solution Fas $58.600 .$, at $21^{\circ}, 745 \mathrm{~mm}$., giving .3605 grame of amino nitrogen in 200.00 . Bolution.

Total Nitrogen in the Piltrate: The emounts of $\mathbb{H} / 10$ aold neutralised were 35.5 and 34.900. . for 25 0c. portions of solution, giving .3942 gram in 200 c0. solution. 
Note: The basic portion of the first woighed sample was lost and a second sample of mutton (2.304 grams) was weighed out, hydrolysed and analysed directly for the basie constituents. In the results given above, the total nitrogen, amino nitrogen and the arginino nitrogen of the basio portion are oslculated from the second weighed sample. The results given in the table below for the basio constituents are calculated by the use of the factor (1.846) representing the ratio between the first and second weighed samples.

\section{Table III.}

Results of Mutton Analysis in Grams and Percentage of

Total Nitrogen.

Weight of protein sample

Weight of totel nitrogen

Per cent of nitrogen in protein

4.254 grams

0.6744 grams

15.85

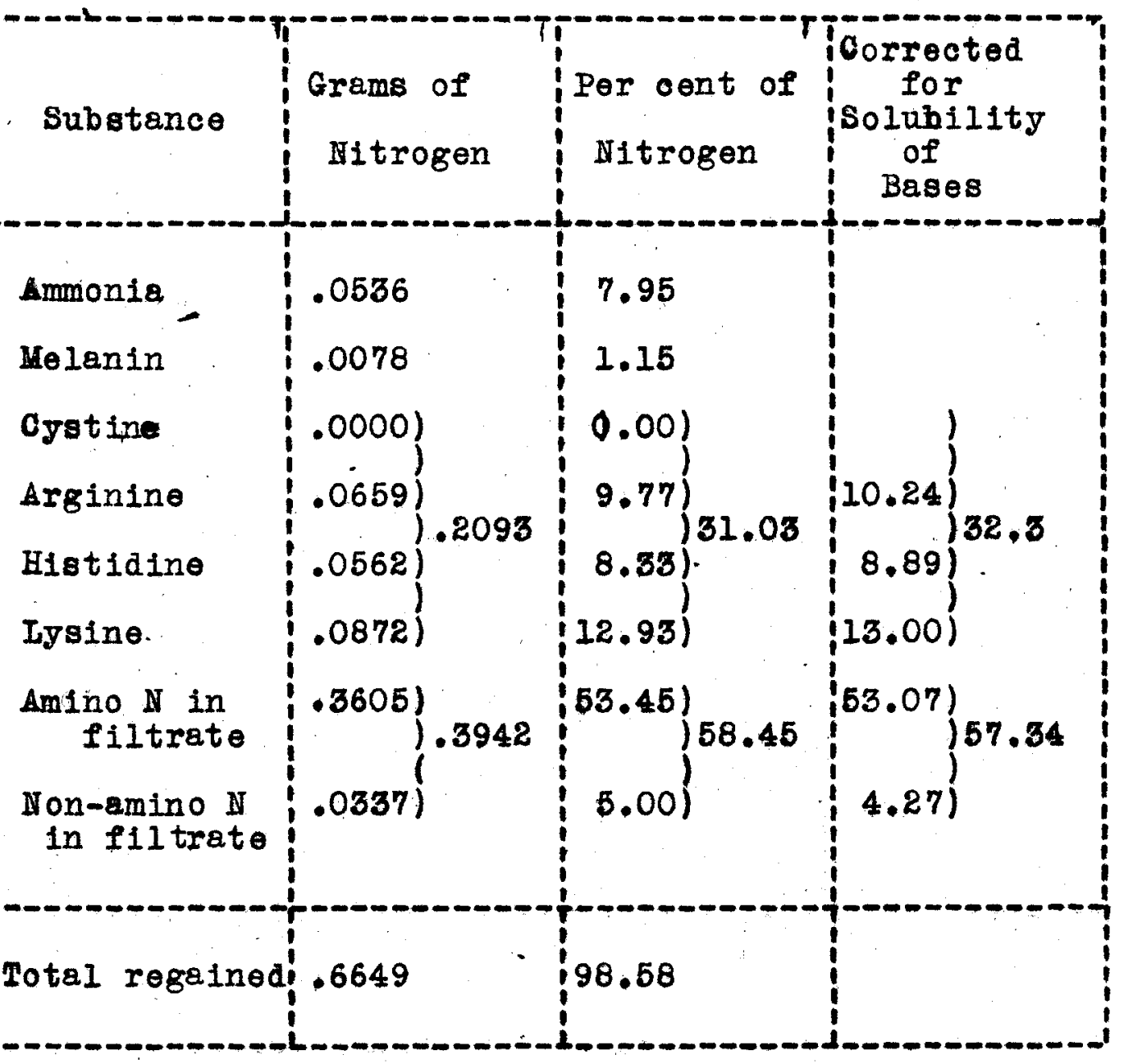


The following table is a comparison of the basto constituents, expressed in percentage of protein, of arginine, histidine and Iysine, based on the foregoing anelyses with that of osborne and Jones of ox musole. These authors also report no eystine present.

Table IV.

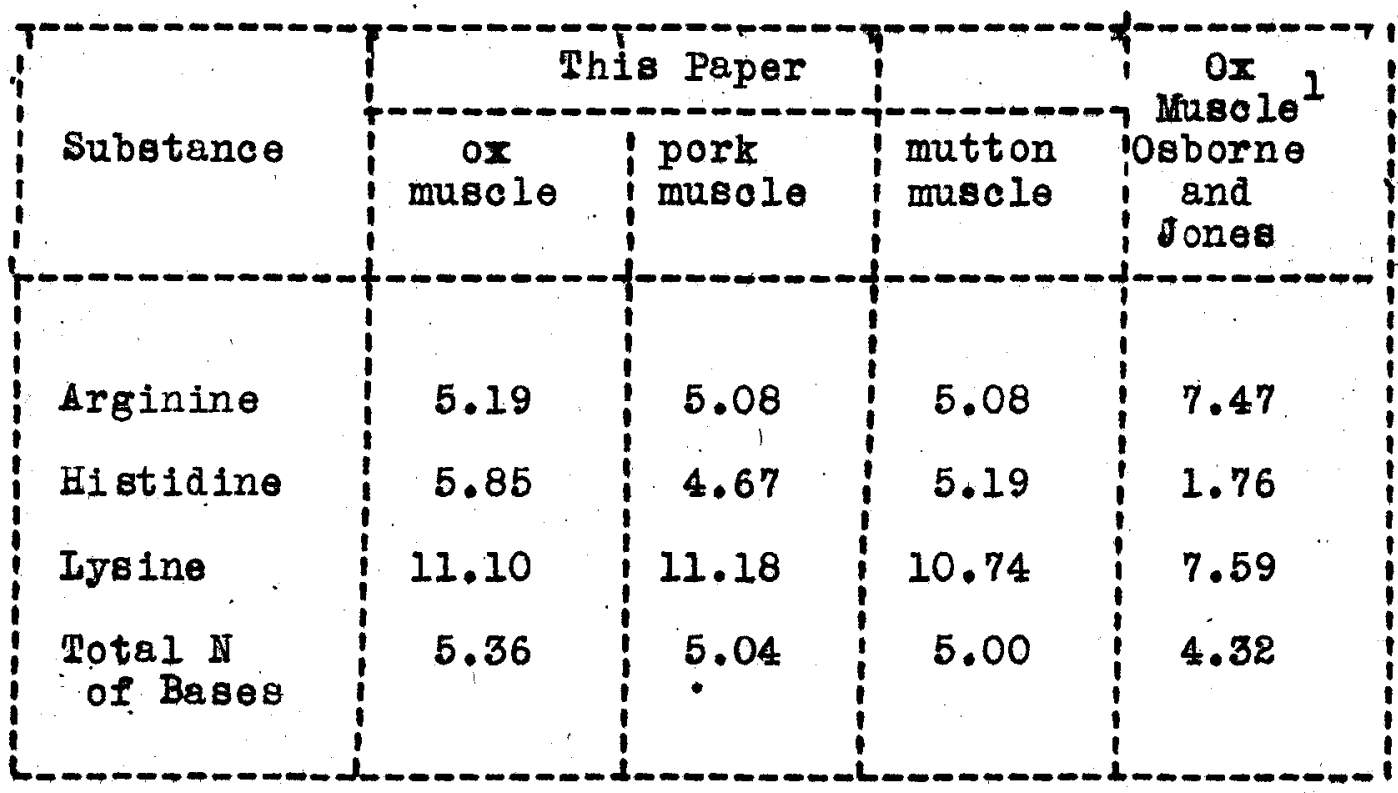

1. Osborne and Jones: Amer. Jour. Physiol: 24, 437 (1909) 
Bramination of the analytioal data obtained in this work shows that:

1. The total nitrogen of the filtrate from the bases is the same in beef, pork, and mutton, but the non-amino nitrogen of the filtrate is somewhat greater ( 2.35 per cent difference) in mutton than in beef and pork, indicating a larger amount of prolin.

2. The total nitrogen of the beses varies somewhat in the thrę, being lowest in the mutton (32.13 per cent), highest in beef ( 34.56 per cent). Arginine and lysine are about the same in all, the chief difference being in the histidine, with a difference of 1.98 per cent between the beef and pork. Since the errors of analyses are laid completely upon the histidine, this difference does not conclusively demonstrete a difference in the composition of the proteins anelysed, especially when it is considered that a difference of 1.63 per cent of nitrogen was obtained in the melanin nitrogen of the pork and beef, the melanin nitrogen being higher in the pork than in the bef, whereas histidine nitrogen is higher in the beef. If it can be considered plausible that the melanin substances are formed during hydrolysis from the basic hydrolytic products, the results indicate complete similarity in the beef and pork, so far as the basic substances are concerned. Likewise a difference of 1.34 per cent in the histidine nitrogen between mutton and beef is protioelzy. compensated by an opposite difference of .80 per cent of melanin nitrogen. Also the total nitrogen recovered in the mutton is only 98.58 per cent. Since the nitrogen 
of the filtrate is the same in mutton and beef it is probable that most of this error of 1.42 per cent is in the basic nitrogen. Addition of this error and of the difference in the beef and mutton melanin nitrogen to the basic nitrogen of the mutton gives 34.35 per cent basic nitrogen, as compared with 34.56 per cent basic nitrogen in the beef.

3. The ammonia nitrogen (amid nitrogen) is about the same in beef, pork and mutton.

The final conclusion to be arawn, is that, with the exception of prolin, there is no apparent difference in the composition of the water insoluble, fat-free proteins of beef, pork and mutton, as far as the Van slyke method demonstrates. Whether the difference in the amount of prolin is real or appears because of experimental error, in the analysis is not clear.

Pinis. 